\title{
The Physicochemical Hydrology of a Humid Tropical River System in South Eastern, Nigeria
}

\author{
Dr Charles Udosen \\ Department of Geography and Natural Resources Management \\ University of Uyo. Uyo, Nigeria \\ chaarlesudosen@gmail.com \\ Dr A. A. Esshiett \\ Dept of Physics, University of Uyo, Uyo, Nigeria
}

\author{
Abasi-Ifreke S. Etok \\ Dept of Geography \\ Akwa Ibom State College of Arts and Science \\ Nung Ukim, Ikono, Akwa Ibom
}

\begin{abstract}
Aspects of the physicochemical parameters of lower Enyong Creek, were investigated for six months at three locations: Ito, Obio Usiere, and Okopedi. Mean concentrations of some of the measured parameters at the sampling locations showed significant statistical differences in channel width $(F=31.48, d f 2<P 0.05)$ ), depth $(F=28.99$, df $2<P 0.05)$, transparency $(F=11.55$, df $2<P 0.05))$, and discharge: $(F=21.45$, df $2<P 0.05))$. Mean differences of the physicochemical parameters were not statistically significant. The variability of the concentrations of the parameters during the period of study was lowest for temperature (3.47\%) and highest for alkalinity (99\%). The mean values of all the physicochemical parameters from all stations did not exceed the recommended limits for life or potable water. The study also shows that morphology of the stream channels in the lower Enyong Creek are influenced by a combination of both local lithologic controls and moderate hydraulic forces
\end{abstract}

Keywords: sodium, potassium, TSS, TDS, Enyong creek

\section{INTRODUCTION}

In the humid tropical environment the peak of the wet season coincides with periods of low evaporation, high rainfall amount, intensity and frequency as well as high ground water recharge rates. These conditions are known to alter both the water quality status and the hydrologic regimes of rivers in the humid tropics Ezekiel et al, 2011, Olatunji and Osibanjo, 2012, Ekpo, et al,2012, Udoh et al, 2013, Dan et al, 2014). These studies have also, highlighted very wide variations in the physicochemical parameters during the wet season in sharp contrast to narrow range of coefficient of variation in dry seasons. Dan et al, 2014 concluded that the seasonal variation, distribution pattern, enrichments and contamination of heavy metals in Qua Iboe river estuary showed elevated concentrations during the wet season months and they attributed this trend to adsorption/dissolution and distribution of the physicochemical parameters viz; temperature, salinity, ${ }_{\mathrm{p}} \mathrm{H}$, TDS, DO, TSS and electrical conductivity. These parameters were also found to be highly variable during wet season.

There is therefore the urgent need to account for the spatial variations in the physicochemical parameters within a drainage system since the various segments or tributaries are known to have variable geomorphometry and they contribute runoff to the main channel at different times. Also, the time of concentration determines the peakedness of unit hydrograph as well as the variations in turbidity, TSS, TDS, electrical conductivity and concentration of nutrients in surface water. It is an index of health and well being of the fluvial system and has direct impact on human health as fish is the main source of protein in Africa.

Physicochemical parameters of water provide nutritional balance and ultimately govern the biotic relationships of organisms in an aquatic ecosystem; including ability to withstand pollution load 
(Udoh et al, 2013). As it is now, most of the studies conducted on the monitoring and assessment of river and estuarine water quality in the Southeastern Nigeria are within the lower and upper Cross River estuary (Lowenberg \& Kunzel 1992; Ekwu \& Sikoki 2006), Calabar River (Asuquo 1999; Okorafor et al, 2013), and a few in the Bonny estuary (Dubbin-Green 1990), New Calabar River (Ekeh \& Sikoki 2003); Mbo River (Essien Ibok et al ,2010) and Nkoro River (Abowei 2010) in the Niger Delta region. Other studies conducted include those of Ikpa River (Ekpo et al, 2012) and Sombreiro River (Ezekiel et al, 2011), Eastern Obolo Estuary (Udoh, 2013).

The lower Enyong Creek is a unique aquatic environment in the humid tropics with marked maritime influence due to riverine inflow, vertical mixing, nutrient enrichment from the riparian vegetation and anthropogenic sources of pollutants from the swamp rice project at Mbiabet Ikpe located in the upper course of Enyong catchment. . It is one of the ecologically and economically rich River systems in southern Nigeria providing breeding grounds for a variety of fish and shrimp species. Geologically, the area under study is underlain by a wide range of diverse geological formations which may alter the adjustments between drainage basin morphometry and fluvial processes within the river basin. This study seeks to provide information on the spatial variation in the physicochemical parameters of surface water in the study area and to enrich the scientific knowledge of intermittent rivers in the humid tropics where little or no information is available for its effective management and sustainability; and to prevent further degradation of the area.

\section{MATERIALS AND MethodS}

\subsection{The Study Area}

The study area lies between latitudes $5^{\circ} 11^{\prime}$ to $5^{\circ} 28^{\prime} \mathrm{N}$ and longitudes $7^{\circ} 51^{\prime}$ to $8^{\circ}$ oo $\mathrm{E}$ (Figure 1 It was traced from toposheet No: Ikot Ekpene 322 NE on 1:50,000 scale.. Geologically, the area under study is underlain by a wide range of diverse geological formations ranging from Asu River Formations the Abakiliki Anticlinorium to the recent alluvium in the south. The Asu River Group underlies most areas in the northern part of the study area e.g its intensely fractured outcrops at Uburu. The Asu River Group, which is Albian in age is sub-divided into three formations, comprising essentially of over $200 \mathrm{~m}$ bluish grey to olive brown shales and sandy shales, fine-grained micacceous and calcareous sandstones and some limestones (Offordile, 2002). The area is well represented by structurally controlled ridges, denudational hills e.g the $150 \mathrm{~m}$ high Obotme conical hill, steep-sided valleys, saddle and col at Obot Ito Ikpo, extensive wetlands and alluvial plains forming soil covers of silty clay, sandy and heavily weathered loamy and alluvium. The area enjoys tropical climate and the temperature ranges from 26 to $32^{\circ} \mathrm{C}$. The fluctuations in temperature are fairly uniform in character, except during the dry months when the rise in temperature is higher than it is during the long wet period (eight months-March to October) and the level of humidity is high (84\%) due to close proximity to the main Cross River Channel.

The average annual rainfall in the basin is $2200 \mathrm{~mm}$ with maximum contribution from southwest tropical maritime air-mass. This study was conducted on three locations along the Enyong Creek viz; stream channels at Ito, Obio Usiere and the lower Enyong Creek at Okopedi (Fig.1)The geographic co-ordinates are listed inTable1.

Table1. Sampling Villages and location.

\begin{tabular}{lll} 
Village & \multicolumn{2}{c}{ Location } \\
Ito & $5^{\circ} 19.227^{\prime} \mathrm{N}$ & $007^{\circ} 56.291^{\prime} \mathrm{E}$ \\
Obio Usiere & $5^{\circ} 15.693^{\prime} \mathrm{N}$ & $007^{\circ} 56.970{ }^{\prime} \mathrm{E}$ \\
Okopedi -Itu & $5^{\circ} 12.144^{\prime} \mathrm{N}$ & $007058.913^{\prime} \mathrm{E}$
\end{tabular}

Sampling was done from the three established sites between June and November, 2014, The water's chemical analysis was done using standard and analytical methods of water analysis (Bartram and Ballance, 1996; APHA - AWWA - WPCF, 2005; USEPA, 1979). Sampling was done at a specific time intervals (i.e10am). At each sampling location, the surface water samples were collected at the middle of the river and stored in a clean polythene bottles that have been pre-washed with nitric acid and thoroughly rinsed with deionized water (Bartram and Balance, 1996). Non-conservable parameters such as temperature, $\mathrm{pH}$ and electrical conductivity were determined, at the time of sampling, in the field (in situ). Water samples were collected approximately $15-20 \mathrm{~cm}$ below the water surface with $125 \mathrm{~cm}^{3}$ using pre-cleaned and chemically neutral 1 litre plastic vessels for laboratory analysis of other physic-chemical parameters. 
Statistical analysis: SPSS package was employed in both descriptive analysis and inferential statistics such as F-ratio (was used to test for site differences in the values of the physicochemical parameters in the water bodies); pair-wise Pearsons Product Moment correlation (PPMC) to establish significant relationship between the physicochemical parameters.

The choice of the sampling stations were based on the contrasting geomorphometry of the subcatchments and possible anthropogenic inputs from activities of transportation, farming practice, domestic and cottage industrial discharges into rivers and streams which finally emptied into main Cross River channel (Fig 1). The lower Enyong Creek is also noted for sea foods which are consumed within and outside the region.

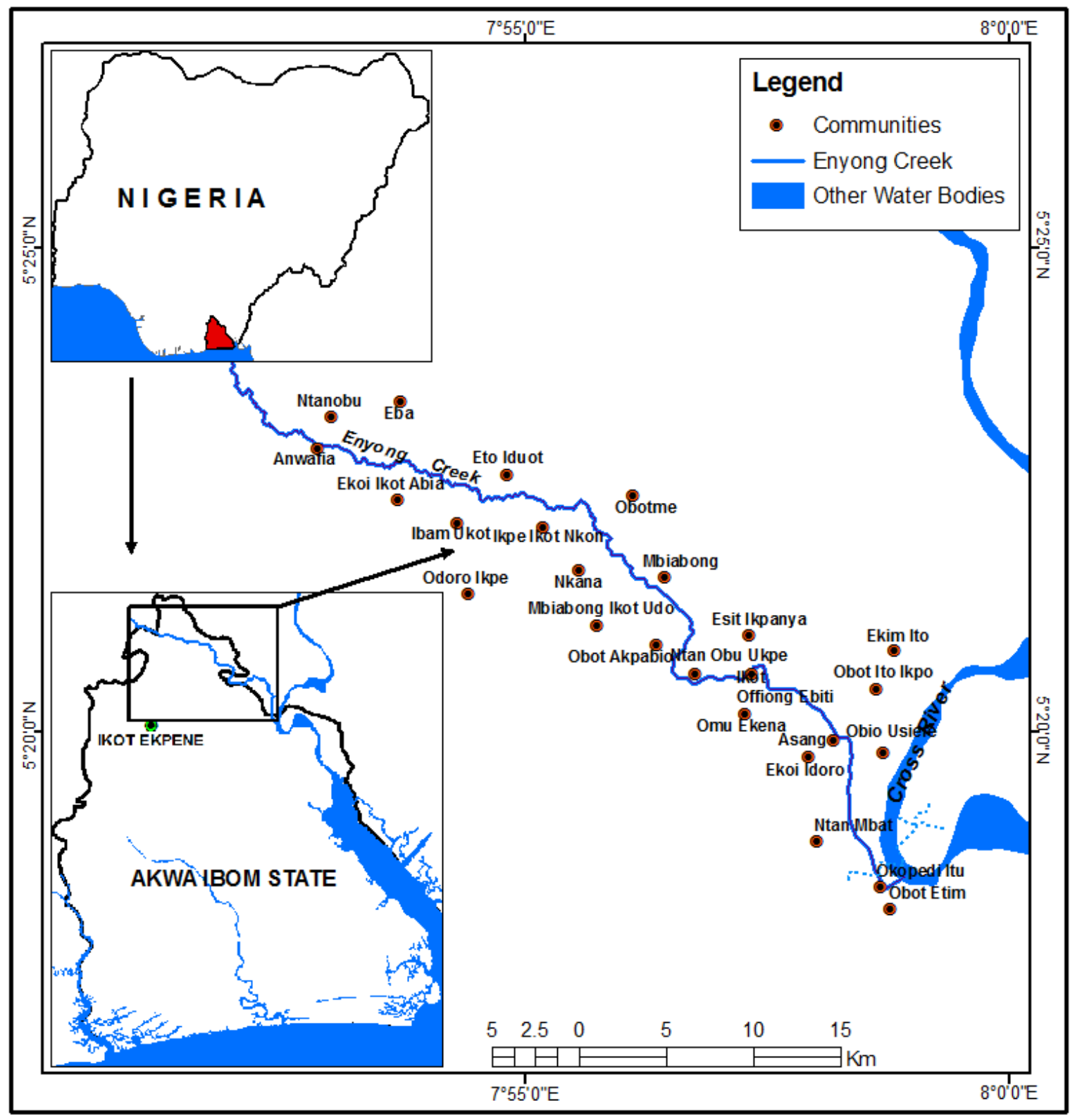

Figure1. Location of Lower Enyong Creek

\section{RESULTS AND DISCUSSION}

Results of physicochemical measurements in the lower Enong Creek are summarized in Table 2. Wide variations in measured parameters were observed at all stations (see also Figs 2, 3 and 4). Some of the parameters with high CVs showed no significant statistical differences in their mean values (Table 3). The concentration of ions reported in this study tended to increase in sampling stations located downstream, and during drier months. The sampling station at Obio Usiere, which is characterized by low gradient (Udosen, et al, in press) experiences partial mixing of the salt water from the Cross River, hence it has elevated values of temperature, ${ }_{\mathrm{p}} \mathrm{H}$, total hardness and sulphate. (Figs 2 and 4) 
Dr Charles Udosen et al.

Tabe2. Spatial variation in the physicochemical parameters in the lower Enyong Creek

\begin{tabular}{|l|l|l|l|}
\hline Parameters & Ito & $\begin{array}{l}\text { Obio } \\
\text { Usiere }\end{array}$ & Okopedi \\
\hline DO & $\mathbf{3 . 2 5} \pm \mathbf{0 . 3 8}$ & $\mathbf{3 . 2 4} \pm \mathbf{0 . 3 7}$ & $\mathbf{3 . 6 7} \pm \mathbf{2 . 7 7}$ \\
\hline Temperature & $\mathbf{2 8 . 3} \pm \mathbf{1 . 2 4}$ & $\mathbf{2 9 . 4} \pm \mathbf{1 . 0 2}$ & $\mathbf{2 8 . 3} \pm \mathbf{0 . 9 9}$ \\
\hline PH & $\mathbf{6 . 0 9} \pm \mathbf{0 . 6 4}$ & $\mathbf{6 . 3 9} \pm \mathbf{0 . 4 4}$ & $\mathbf{6 . 0} \pm \mathbf{0 . 5 9}$ \\
\hline BOD & $\mathbf{0 . 3} \pm \mathbf{0 . 1 6}$ & $\mathbf{1 . 4 0} \pm \mathbf{0 . 9 8}$ & $\mathbf{1 . 9 6} \pm \mathbf{0 . 2 7}$ \\
\hline Electrical conductivity & $\mathbf{2 8 . 5} \pm \mathbf{1 9 . 4}$ & $\mathbf{2 8 . 6} \pm \mathbf{1 3 . 1 3}$ & $\mathbf{3 9 . 4} \pm \mathbf{3 . 6 1}$ \\
\hline Salinity & $\mathbf{0 . 3 3} \pm \mathbf{0 . 1 1}$ & $\mathbf{0 . 2 6} \pm \mathbf{0 . 0 0 9}$ & $\mathbf{0 . 2 2} \pm \mathbf{0 . 1 5}$ \\
\hline TSS & $\mathbf{0 . 0 1 7} \pm \mathbf{0 . 0 0 2}$ & $\mathbf{0 . 0 0 0 2} \pm \mathbf{0 . 0 0 0 1}$ & $\mathbf{0 . 0 1} \pm \mathbf{0 . 0 0 7}$ \\
\hline TDS & $\mathbf{1 0 . 5} \pm \mathbf{3 . 3 4}$ & $\mathbf{5 . 8 7} \pm \mathbf{1 . 6 8}$ & $\mathbf{7 . 3 7} \pm \mathbf{5 . 8 7}$ \\
\hline Hardness & $\mathbf{5 . 7 7} \pm \mathbf{0 . 6 3}$ & $\mathbf{7 . 7 7} \pm \mathbf{2 . 1 6}$ & $\mathbf{7 . 8 8} \pm \mathbf{3 . 3 5}$ \\
\hline Alkalinity & $102.7 \pm 51.9$ & $90.7 \pm 59.1$ & $99.4 \pm 63.4$ \\
Nitrate & $1.96 \pm 0.71$ & $2.02 \pm 0.73$ & $2.05 \pm 1.22$ \\
Sulphate & $5.88 \pm 0.12$ & $6.40 \pm 1.61$ & $6.40 \pm 2.6$ \\
Calcium & $26.24 \pm 7.27$ & $26.17 \pm 7.5$ & $26.6 \pm 15.4$ \\
Magnesium & $7.62 \pm 1.8$ & $7.14 \pm 2.48$ & $6.47 \pm 2.15$ \\
Sodium & $0.19 \pm 0.08$ & $0.35 \pm 0.26$ & $0.42 \pm 0.23$ \\
Ammonium & $3.09 \pm 1.73$ & $2.96 \pm 1.86$ & $2.85 \pm 1.76$ \\
Potassium & $0.34 \pm 0.18$ & $0.33 \pm 0.17$ & $0.20 \pm 0.10$ \\
Transparency & $87.2 \pm 4.58$ & $74.2 \pm 3.75$ & $43.1 \pm 3.11$ \\
Channel width $(\mathrm{m})$ & $28.8 \pm 1.65$ & $89.4 \pm 2.32$ & $69.5 \pm 3.21$ \\
Channel depth $(\mathrm{m})$ & $3.68 \pm 1.24$ & $4.78 \pm 0.98$ & $8.3 \pm 0.83$ \\
Velocity $(m)^{-3}$ ) & $0.188 \pm 0.08$ & $0.23 \pm 0.078$ & $0.29 \pm 0.81$ \\
discharge & $19,9 \pm 01.56$ & $107.2 \pm 3.57$ & $215.6 \pm 3.67$ \\
\hline & & & \\
\hline
\end{tabular}

Source: Data analysis, 2016

Mean values of all the parameters studied showed seasonal variations but with a gradual decrease as the rain progressed. In order to assess the quality of the water at the stations, the mean values of the parameters were compared with international permissible limits for inland waters and for drinking water (Table 3). The mean values of, DO, hardness, calcium, nitrate, magnesium, TSS, sodium, and biochemical oxygen demand from all stations did not exceed the recommended limits for aquatic life or potable water.

Some of the channel cross- sectional variables viz: channel width, depth, discharge and transparency $(\mathrm{cm})$ showed statistically significant difference $(\mathrm{P}<0.05)$. The mean and standard deviation values of channel depths were $3.68 \pm 1.24,4.78 \pm 0.98$ and $8.3 \pm 0.83$ metres for the three stations with the highest mean value recorded downstream at Okopedi and the lowest value recorded at Ito. Channel width had its widest reach at Obio Usiere $(89.4 \pm 2.32 \mathrm{~m})$, while the channel velocity values varied from $0.188 \pm 0.08 \mathrm{~m} / \mathrm{s}^{3}$ at Ito to $0.29 \pm 0.81 \mathrm{~m} / \mathrm{s}^{-}{ }^{3}$ in Okopedi. Current velocity was the only cross-sectional variable that did not show statistically significant difference among the sampling points.. Transparency values exceeded values recorded in Ikpa River by Ekpo, et al,( 2012) but compared favourably with those of Mbo River, which ranged from $40 \mathrm{~cm}$ to $70 \mathrm{~cm}$ (Essien Ibok, 2010)., The mean and standard deviation values were 87.2 $\pm 4.58,74.2 \pm 3.75$ and $43.1 \pm 3.11$ for Ito, Obio Usiere and Okopedi respectively. Values for discharge increased progressively downstream 19,9 \pm 01.56 , 107.2 \pm 3.57 and $215.6 \pm 3.67$ cubic metres/sec respectively.

Table3. Summary of Analysis of Variance showing parameters with significant mean differences and Coefficients of variation (CV\%) among the three locations in Lower Enyong Creek S.E, Nigeria

\begin{tabular}{|l|l|l|l|l|l|}
\hline Parameters & Ito & $\begin{array}{l}\text { Obio } \\
\text { Usiere }\end{array}$ & Okopedi & $\begin{array}{l}\text { Permissible } \\
\text { level }\end{array}$ & $\begin{array}{l}\text { ANOVA } \\
\text { calculated F-value }\end{array}$ \\
\hline DO (mg/l) & $3.25(11.69 \%)$ & $3.24(11.42 \%)$ & $3.67(75.48 \%)$ & $5.0 \mathrm{mg} / \mathrm{l}$ & 0.15 \\
\hline Temperature & $28.3(4.38 \%)$ & $29.4(3.47 \%)$ & $28.3(3.50 \%)$ & - & 1.72 \\
\hline $\mathrm{pH}$ & $6.09(10.51 \%)$ & $6.39(6.89 \%)$ & $6.0(9.83 \%)$ & $6.5-9.2$ & 0.45 \\
\hline Depth $(\mathrm{m})$ & $3.64(48.19 \%)^{*}$ & $4.77(11.64 \%)^{*}$ & $8.33(69.39 \%)^{*}$ & & 28.99 \\
\hline Width $(\mathrm{m})$ & $28.8(12.89 \%)^{*}$ & $75.92(23.47 \%)^{*}$ & $69.5(4.71 \%)^{*}$ & & 31.49 \\
\hline
\end{tabular}


The Physicochemical Hydrology of a Humid Tropical River System in South Eastern, Nigeria

\begin{tabular}{|l|l|l|l|l|l|}
\hline BOD(mg/l) & $0.3(53.3 \%)$ & $1.40(70 \%)$ & $1.96(13.78 \%)$ & $50 \mathrm{mg} / \mathrm{l}$ & 1.70 \\
\hline $\begin{array}{l}\text { Electrical } \\
\text { conductivity }\end{array}$ & $28.5(68.07 \%)$ & $28.6(45.91 \%)$ & $39.4(9.16 \%)$ & - & 0.143 \\
\hline Velocity $\left(\mathrm{ms}^{-3)}\right.$ & $0.19(64.74 \%)$ & $0.23(91 \%)$ & $0.28(28.93 \%)$ & - & 0.50 \\
\hline Discharge & $19.91(30.13 \%)$ & $107.28(44.26 \%)^{*}$ & $215.6(40.97 \%)$ & - & 21.45 \\
\hline Salinity & $0.33(33.33 \%)$ & $0.26(3.46 \%)$ & $0.22(68.18 \%)$ & - & 0.026 \\
\hline TSS & $0.017(11.77 \%)$ & $0.0002(50 \%)$ & $0.01(70 \%)$ & $1,500 \mathrm{mg} / 1$ & 0.071 \\
\hline TDS & $10.5(31.81 \%)$ & $5.87(28.62 \%)$ & $7.37(79.65 \%)$ & - & 0.54 \\
\hline Hardness & $5.77(10.92 \%)$ & $7.77(27.8 \%)$ & $7.88(42.51 \%)$ & $120 \mathrm{mg} / 1$ & 1.14 \\
\hline Alkalinity & $102.7(50.54 \%)$ & $90.7(65.16 \%)$ & $99.4(63.78 \%)$ & - & 0.068 \\
\hline Nitrate (mg/l) & $1.96(36.22 \%)$ & $2.02(36.14 \%)$ & $2.05(59.51 \%)$ & $10 \mathrm{mg} / \mathrm{l}$ & 0.94 \\
\hline Sulphate(mg/l) & $5.88(2.04 \%)$ & $6.40(25.16 \%)$ & $6.40(40.63 \%)$ & $400 \mathrm{mg} / 1$ & 0.0056 \\
\hline Calcium(mg/l) & $26.24(27.71 \%)$ & $26.17(28.66 \%)$ & $26.6(57.9 \%)$ & $200 \mathrm{mg} / \mathrm{l}$ & 0.0024 \\
\hline Magnesium & $7.62(23.62 \%)$ & $7.14(34.73 \%)$ & $6.47(33.23 \%)$ & $150 \mathrm{mg} / \mathrm{l}$ & 0.432 \\
\hline Sodium (mg/l) & $0.19(42.11 \%)$ & $0.35(74.28 \%)$ & $0.42(54.76 \%)$ & - & 1.12 \\
\hline Ammonium & $3.09(55.99 \%)$ & $2.96(62.84 \%)$ & $2.85(61.75 \%)$ & - & 0.027 \\
\hline Potassium (mg/l) & $0.34(52.94 \%)$ & $0.33(50 \%)$ & $0.20(50 \%)$ & - & 0.83 \\
\hline $\begin{array}{l}\text { Transparency } \\
(\mathrm{cm})\end{array}$ & $\begin{array}{l}87.17 \\
(11.72 \%) *\end{array}$ & $74.2(46.85 \%) *$ & $43(39.94 \%) *$ & - & 11.55 \\
\hline
\end{tabular}

Table value of analysis of variance $=3.68 \wedge$ significant at 0.05 level

Both velocity and discharge are known to be highly variable (CV ranges from 29 to $91 \%$ and 30 to $44.3 \%$ respectively (Table 3 ). The highly variable stream discharge rate coupled with inflow from the main Cross River channel during the dry season perform the role of diluting and removing nutrients, ammonium, potassium and magnesium, hence they showed significant spatial variations decreasing downstream, (Figures 2-4, although it was not statistically significant at $\mathrm{P}<0.05, \mathrm{n}=18$ ).

\section{Dissolved Oxygen (DO)}

$D O$ is essential to all forms of aquatic life and varies with temperature, turbulence, atmospheric pressure and photosynthetic activity of algae and plants. The dissolved oxygen range in the current study was within the acceptable range and displayed wide but significant spatial differences (Fig. 2A). Mean DO was $3.25 \pm 0.38 \mathrm{mgL}-1$ at Ito, $3.67 \pm 2.77$ at Okpedi, with a dip at Obio Usiere (3.24 mgL-1). The spatial difference in dissolved oxygen values was however not significant $(\mathrm{P}<0.05)$. Higher DO values (8.25 mgL- $9.93 \mathrm{mgL}-1)$ were reported for Woji Creek (Hart \& Zabbey 2005; Davies et al. 2008) and in Okpoko River (Abowei \& George 2009) and in Eastern Obolo (Udoh, et al, 2013], all in the Niger Delta area of Nigeria. It would be recalled that coastal waters typically require a minimum of $4.0 \mathrm{mgL}-1$ but do better with $5.0 \mathrm{mgL}-1$ of oxygen to provide for optimum ecosystem function and highest carrying capacity (UNESCO/WHO (1978). However, the present study area is not located along the coast. Dissolved oxygen (DO) concentration in natural waters depends on the physical, chemical and biochemical activities in the water body. DO values recorded during the study period were lower than FMENV permissible limit of $5.0 \mathrm{mg} / \mathrm{l}$. The depletion of DO at the lower Enyong Creek stations could also be due to enormous amount of organic loads which required high levels of oxygen for chemical oxidation, decomposition or break down. Similar findings have been reported by some authors (Morenikeji and Raheem, 2008; Chukwu et al.,2008 and Andem et al., 2012). DO is very crucial for the survival of aquatic life and it is also used to evaluate the degree of freshness of a river. A DO level as low as between $1-5 \mathrm{mg} / \mathrm{L}$ will slow down the growth of fishes when continuously exposed, while levels below $1 \mathrm{mg} / \mathrm{L}$ are reported to be lethal to fish when exposed more than a few hours (Andem, et al., 2012).

\section{$\mathrm{PH}$}

The mean $\mathrm{pH}$ values were well within the acceptable range for drinking water (6.5 to 8.5), optimal aquatic productivity (6.5 to 9.0) and livable range of 5.5 to 10 (Wetzel 2001). Similar trends (5.308.10) were reported in Ikpa River, which drains settlements south of Enyong Creek (Ekpo et al, 2012). The $\mathrm{pH}$ values obtained are characteristic of tidal fresh water environment (Ajao \& Fagade 2000). 
Significant decrease in $\mathrm{pH}$ values were also observed at Ito and Okopedi sampling stations (Fig. 2D). The $\mathrm{pH}$ of an aquatic system is an indicator of the water quality and the extent of pollution in the watershed (Jonnalagadda and Mhere, 2001). Change in $\mathrm{pH}$ may hold dire consequences for the health of aquatic organisms since most of their metabolic activities are $\mathrm{pH}$ dependent (Morgan and McManhon, 1982; Chen and Lin, 1995).
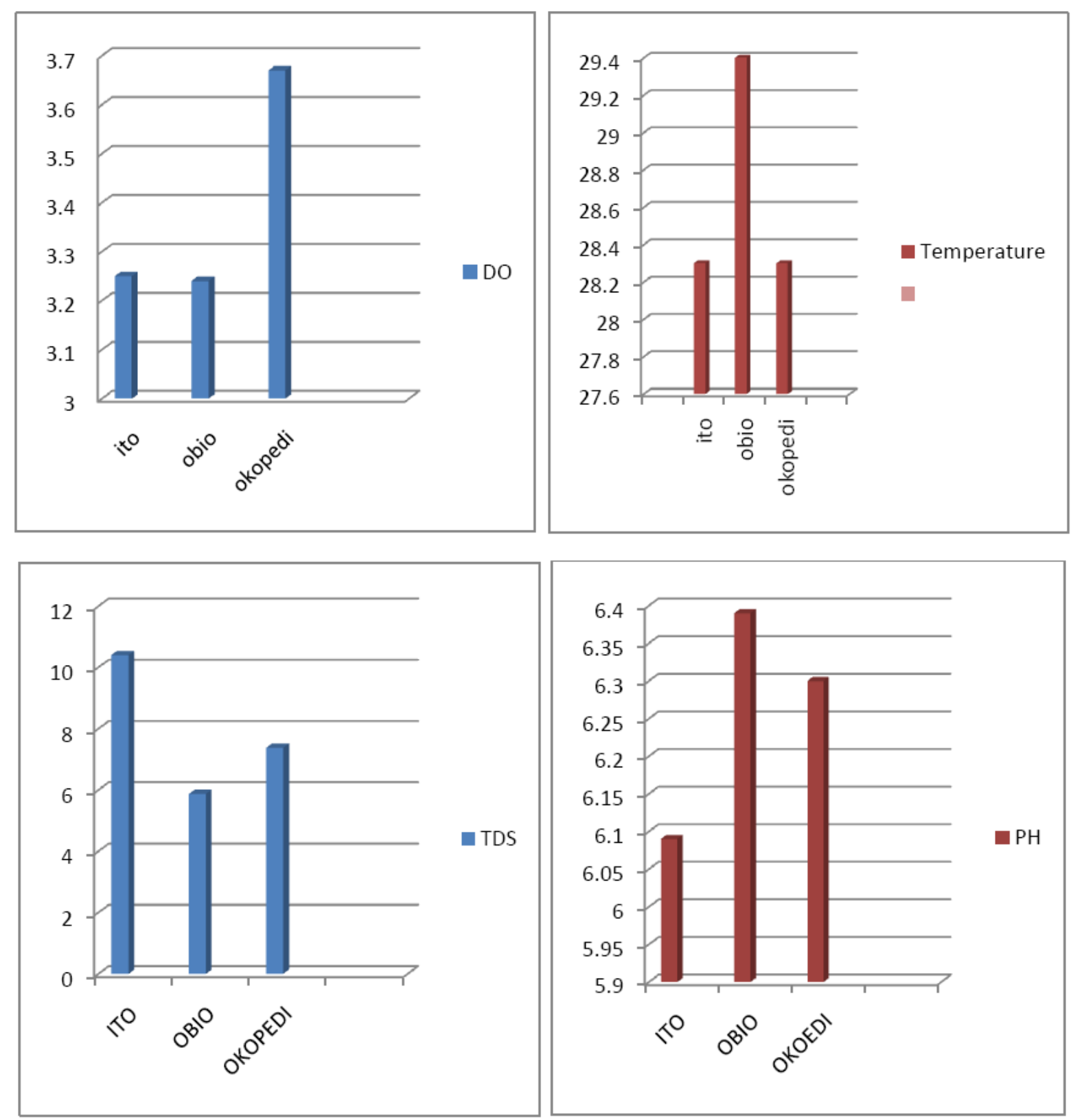

Fig2. Spatial variation in $D O(A)$ temperature $(B), T D S(C)$ and ${ }_{P} H,(D)$

\section{Total Dissolved Solid (TDS)}

TDS is a convenient measure of the total ionic concentration in water. Large amounts of dissolved solids can lead to increased mineralization of the receiving waterway with the consequence of dissolved oxygen depletion (Akpan 1991). Concentrations of total dissolved solids (TDS) or non-filterable residue in the study area showed statistically insignificant difference $(\mathrm{P}<0.05)$ but wide spatial variations between the sampling stations with the lowest values recorded at Obio Usiere $(5.87 \pm 1.68 \mathrm{mgL}-1)$ and the highest $(10.5 \pm 3.34 \mathrm{mgL}-1)$ recorded upstream at Ito, which has higher basin relief, steeper channel slope and consequently higher values of TDS (Fig. 2C). In contrast, Udoh et al (2013) observed that TDS levels increased significantly towards the sea during drier months in Eastern Obolo Estuary. The observed TDS values (5.87 -10.45 mgL-1) are below the permissible limits (500 mg L-1) adopted by WHO (1984), FEPA (1991), and Federal Ministry for Environment, Nigeria (Udoessien 2003) for aquatic organisms. 

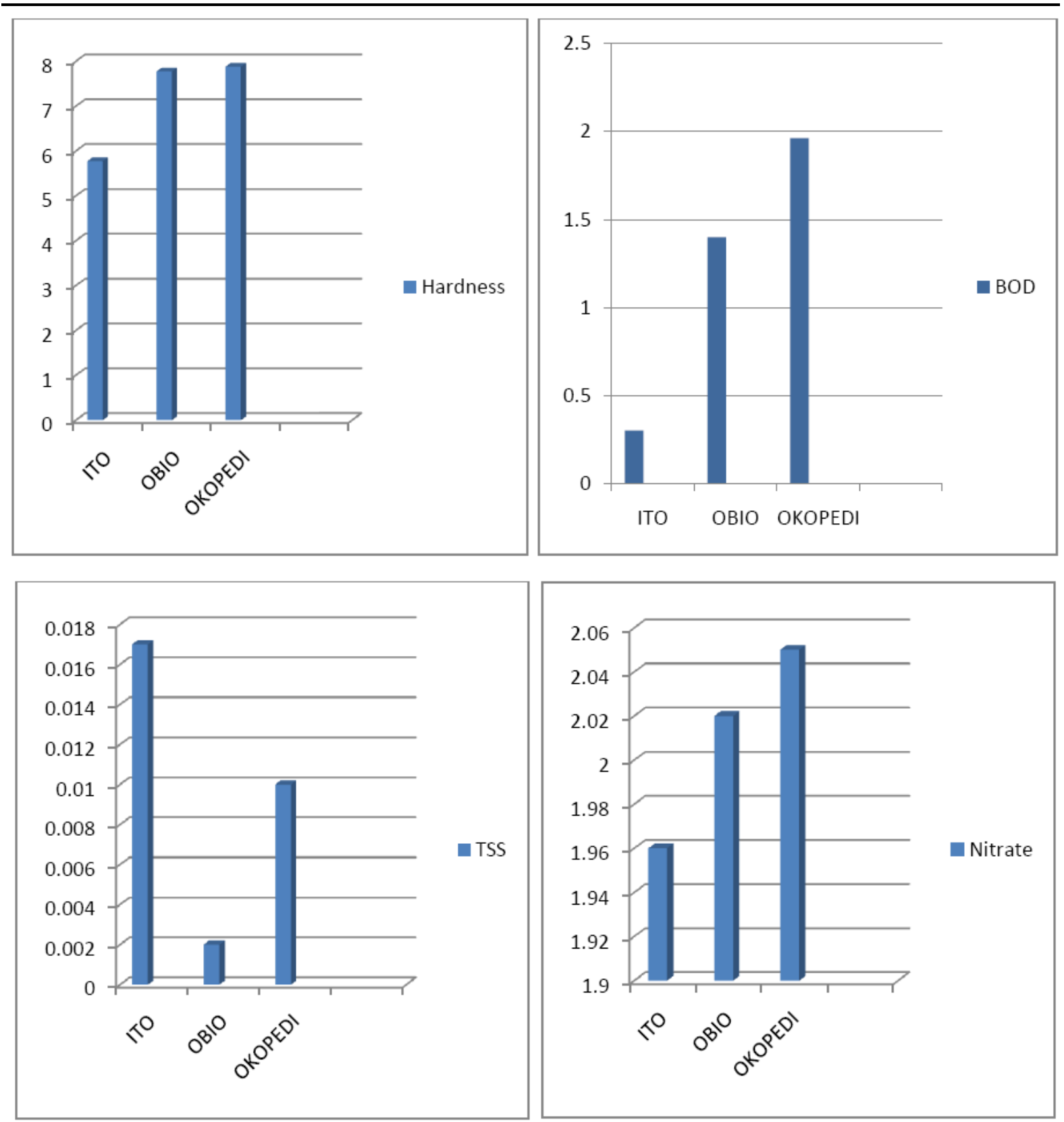

Figure3. Spatio temporal variation of Hardness $(A), B O D(B), T S S(C) \&$ Nitrate $(D)$

\section{Biochemical Oxygen Demand (BOD)}

BOD indicates the degree of microbial mediated oxygen consumption by contaminants in water, i.e., the amount of dissolved oxygen used in the oxidation process. Oxygen depletion brings about the growth of anaerobes which can breakdown organic matter using sulphates and nitrates, in the absence of dissolved oxygen, to release hydrogen sulphide and ammonia gases above permissible limit) The range in BOD $(<2.0 \mathrm{mg} / \mathrm{l})$ is below values indicative of pollution $(<50 \mathrm{mg} / \mathrm{l})$, similar to the observations of Ubong \& Gobo (2001) but differs with the values $(1.32-6.8 \mathrm{mg} \mathrm{L}-1)$ obtained in New Calabar River (Ekeh \& Sikoki 2003). Generally, BOD depends on temperature, extent of biochemical activities, concentration of organic matter and such other related factors. The low level of BOD values recorded in this study could be due to the volume and surface area (wide channels) of the rivers or streams in the downstream of Enyong Creek. DO values were higher than BOD values in all the stations.

\section{Nitrate}

Nitrate values during the study period were below $10 \mathrm{mg} / \mathrm{L}$ permissible limit by (FMENV, 1999). The source of nitrate could be from oxidation of other forms of nitrogen compounds like ammonia and nitrite into nitrate and it increases from $<2 \mathrm{mg} / \mathrm{l}$ at Ito to $2.05 \mathrm{mg} / \mathrm{l}$ at Okopedi (Fig.3D). 


\section{TSS}

Total suspended solid (TSS) is the sum total of the suspended solid particles. TSS values were low (particularly at Obio Usiere $(0.0002 \pm 0.0001$, with a cv of $50 \%)$ when compared to the maximum permissible limit of $1500 \mathrm{mg} / \mathrm{l}$ set by (WHO, 1997). This could be as a result of tidal influence of the river.

\section{Sulphate}

Sulphate showed remarkable uniformity at Obio Usiere and Okopedi (both had 6.40mg/l) compared to $5.88 \mathrm{mg} / \mathrm{l}$ at Ito with a very low coefficient of variation of $2.05 \%$ (Fig.4A). The main source of sulphate is cretaceous aquifer through chemical weathering-oxidation processes, Sulphate concentrations indicated quantum increase downstream from additional tributaries of very short anabranching streams
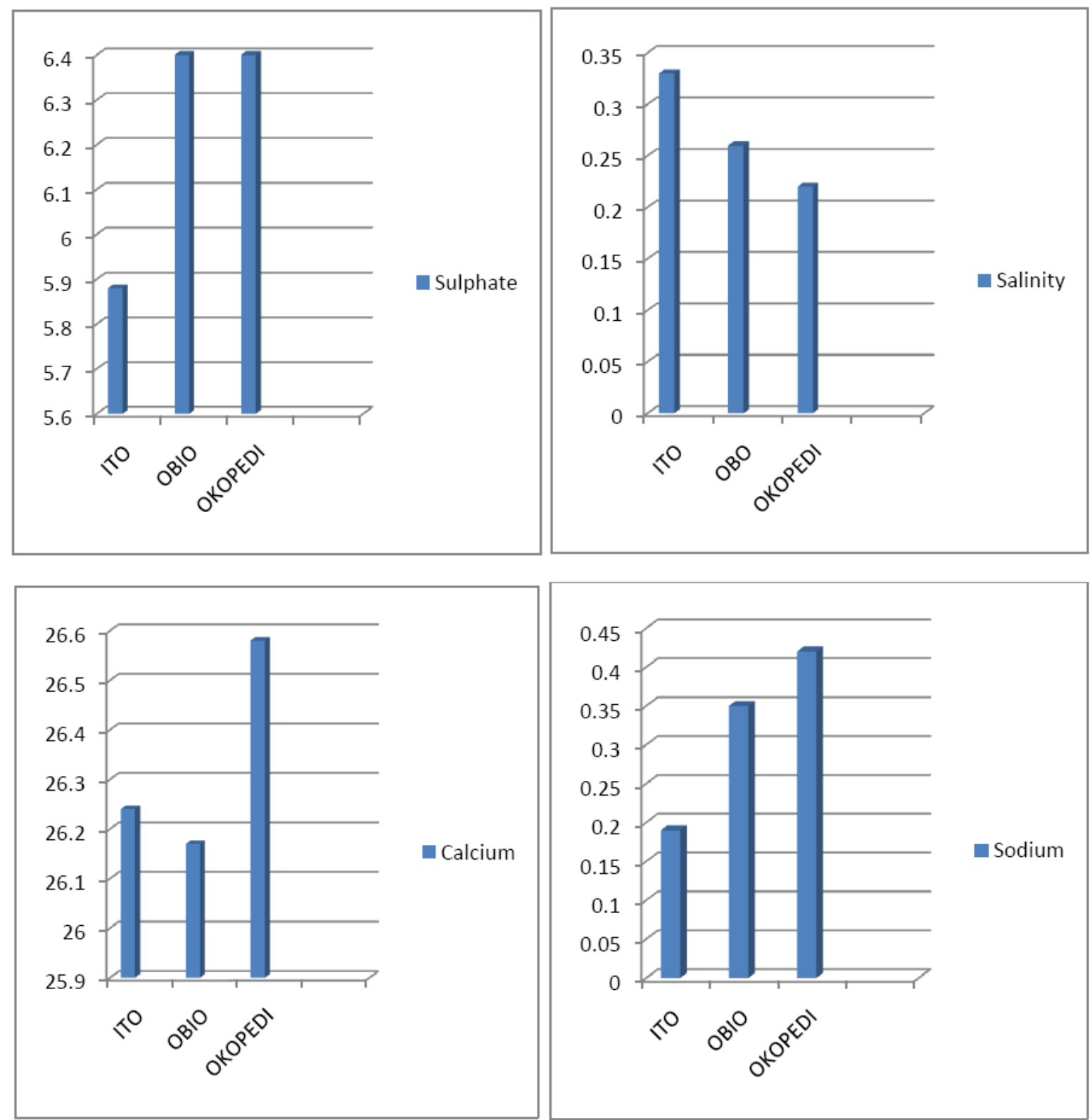

Figure4. Spatio temporal variation of Sulphate (A), Salinity (B) Calcium (C) \&Na (D)

\section{Salinity}

The result of this study showed significant drop in salinity in a downstream direction between stations (Fig. 4B), because the catchment is highly vulnerable to external perturbations and mixing of freshwater with saline water from main Cross River system, (Fig 1). However, salinity at Ito, Obio Usiere and Okopedi were not significantly different from each other. Similar observations were made by Lowenberg \& Kunzel (1992), for the Cross River while Abowei \& George (2009) and Abowei (2010), differ in their report of no significant difference in salinity between sampling stations, $(\mathrm{P}<0.05)$, along Okpoka Creek and Nkoro River, respectively; 
largely due to the fact that water at these sampling stations were from same source (linear in nature). The high freshwater discharge during the wet months is responsible for the low variability. However, during the dry season, rainfall recedes and discharges from most tributaries cease thereby increasing inflow of salt water.

\section{Electrical conductivity}

Conductivity is a measure of conducting ionic species in a sample solution. Low level of conductivity recorded during the study period could be attributed to the low levels of conducting species such as chloride, phosphate and heavy metals present in the stations (Udosen et al,2016 in press)). This affirms the study of Fakayode (2005) in Alaro stream, Ibadan. Upstream stations had the least conductivity value of $28.5 \pm 19.4$ and $28.6 \pm 13.13 \mu \mathrm{S} \mathrm{cm} \mathrm{cm}-1$ (Fig. $5 \mathrm{~A}$ ).

\section{Potassium, Ammonium and Magnesium}

Potassium, Ammonium and Magnesium values recorded in this study did not exceed WHO limits and decrease steadily downstream (Fig. 5B-D). Ammonium for instance decreased progressively from 3.09 (cv55.99\%); 2.96 (cv62.84\%) and 2.85 (cv61.75\%) for Ito, Obio Usiere and Okopedi respectively.
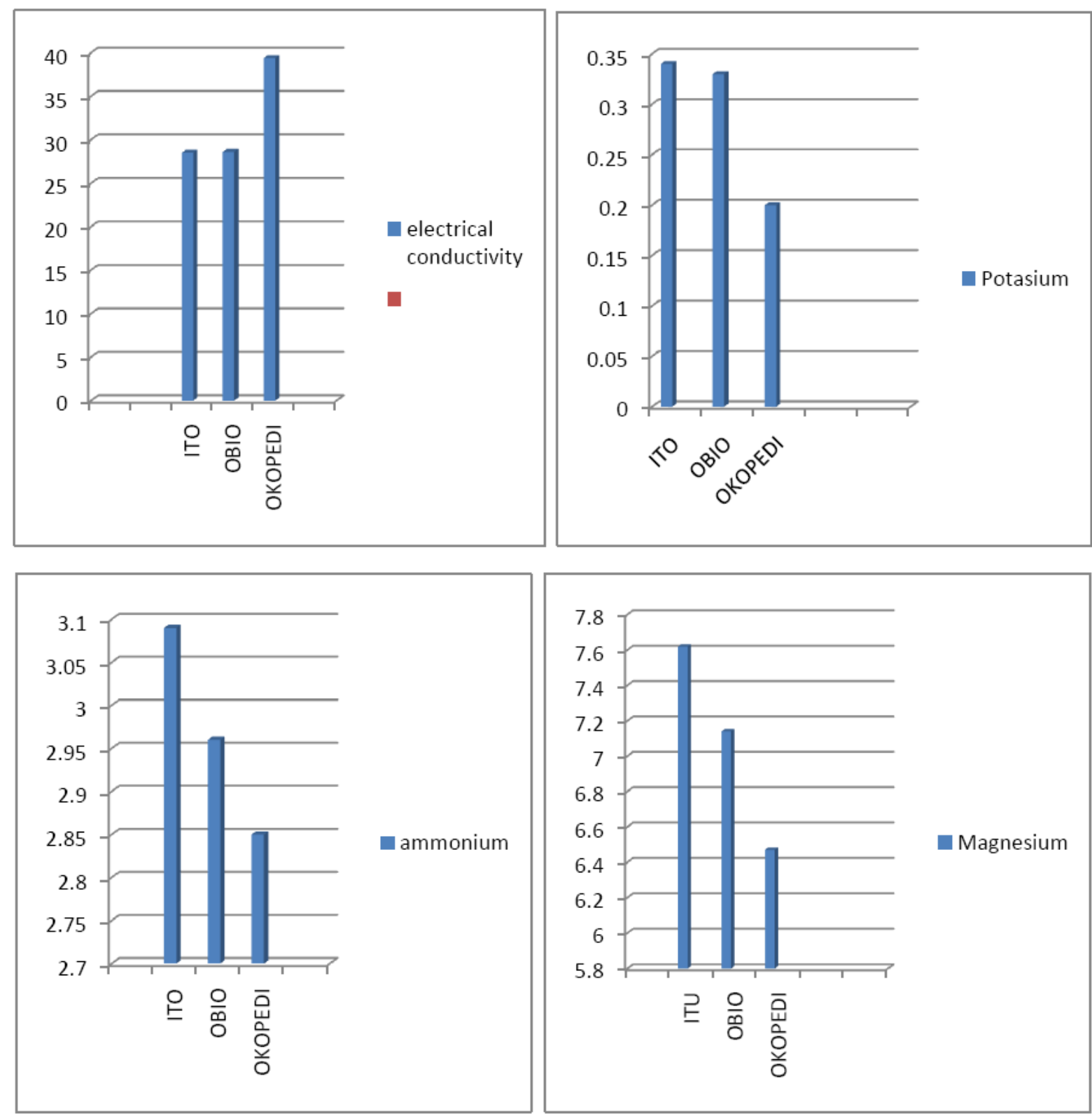

Figure5. Spatio temporal variation of Conductivity (A), $K(B)$, Ammonium $(C) \& M g(D)$

Downstream hydraulic geometry (Fig. 6A-D) characterizes systematic downstream changes in channel geometry (channel width, depth, velocity) as power-law relationships with discharge, and may be used to quantify the influence of fluvial controls on channel form (Leopold and Maddock 


\section{Dr Charles Udosen et al.}

1953). However, the complicated hydraulics and sediment transport processes associated with the lower Enyong Creek characterized by heterogeneity in geology may confound these relationships (Udosen, et al, 2016 in press). More so, most geomorphologists are under the impression that the velocity of a stream is greater in the headwaters than in the lower reaches. In the present study, current velocity increases downstream pre-supposing that the rate of increase of depth downstream tends to overcompensate for the decreasing slope and tends to provide a net increase of velocity at mean annual discharge in the downstream direction of a river.
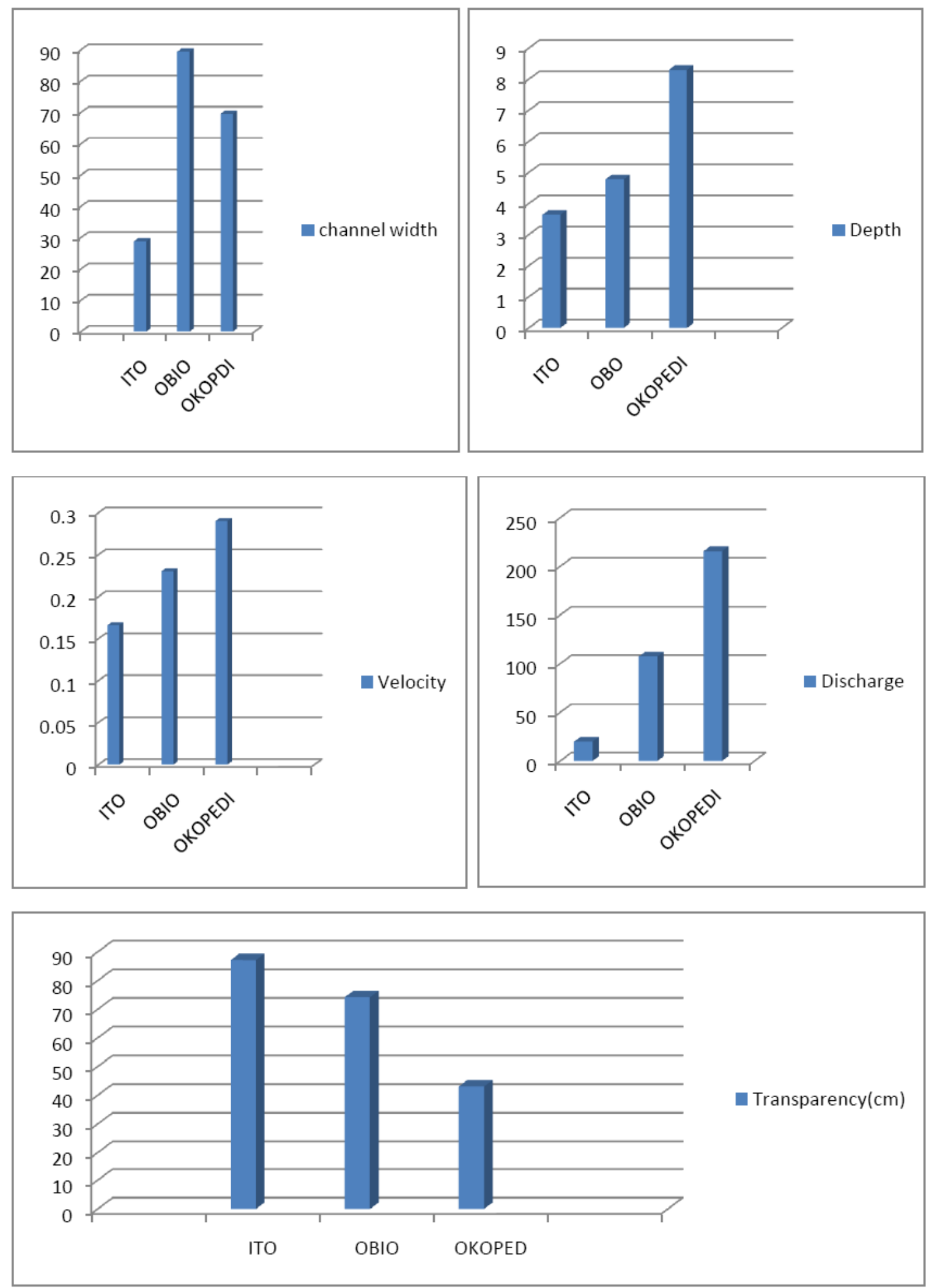

Figure6. Spatio temporal variation of Channel Width, depth, velocity, discharge \& transparency 
The decreasing transparency downstream in the Lower Enyong Creek is expected, and is contingent on inflow from numerous additional sub-catchments in the fairly flat floodplains along with suspended solutes, bed load materials and increased plankton abundance (Fig. 6 E). The spatial variation in transparency, which decreased from $87.17 \pm 4.58 \mathrm{~cm}$ (cv11.72\%), at Ito to $43 \mathrm{~cm} \pm 3.11$ (cv39.94\%) at Okopedi is statistically significant at ( $<<0.05$ ), with F-value of 11.55 (Table 3).

Matrix of correlation coefficients between the physicochemical and hydrologic parameters in the surface water in the Lower Enyong Creek monitored for six (6) months (Table 4) indicates that only discharge and channel depth (0.81); velocity and conductivity $(0.81)$ and calcium and nitrate $(0.80)$ relationships were significant at $(\mathrm{P}<0.001)$. These high correlation coefficients indicate that the adjustments in channel geometry downstream depends more on channel depth (as discharge correlates strongly with depth. The relationship between calcium and nitrate indicates common lithological or crustal sources for the elements rather than the anthropogenic sources(Turekian, 1977). Their sources are essentially natural through geological modification -dissolution from cretaceous rocks. Also, Ca correlates moderately strong with TDS $(-0.54)$ and alkalinity $(-0.48)$, while nitrate shows negative relationships with salinity $(-0.61)$ and TDS $(-0.64)$. These relationships are significant at $(\mathrm{P}<0.05)$. Apart from channel depth, discharge was also found to correlate with BOD (0.54) channel width $(0.52)$ and current velocity $(0.52)$. Similarly, current velocity showed positive correlations with BOD (0.64); width (0.54) and depth (0.52).

Pearson correlation coefficient indicates a negative relationship between transparency and DO (-.0.48) in sharp contrast to the highly significant positive relationship between transparency and DO (0.82) in Mbo River, near the coast of south eastern Nigeria (Essien-Ibok, 2010). The relationship between sulphate and TDS and alkalinity were also significantly strong (0.71) and (0.62), all significant at $\mathrm{P}<0.05)$. Other significant relationships were BOD versus conductivity $(0.48)$, width $(0.63)$ and alkalinity (-0.64); channel depth versus $\mathrm{Na}(0.50)$; ammonium versus potassium $(-0.49)$; alkalinity versus TDS (0.51) and TSS (0.61) etc.

Table4. Correlation matrix of Physicochemical / hydrologic parameters in lower Enyong Creek

\begin{tabular}{|c|c|c|c|c|c|c|c|c|c|}
\hline Parameter & Salinity & TDS & Total SS & Hardness & Alkalinity & Sulphate & DO & Nitrate & calcium \\
\hline Sal. & - & & & & & & & & \\
\hline TDS & .34 & - & & & & & & & \\
\hline TSS & -.31 & -.21 & - & & & & & & \\
\hline Hard & .28 & .16 & -.24 & - & & & & & \\
\hline Alka & .31 & $.51 *$ & $.61 *$ & .29 & - & & & & \\
\hline Sulp & -.13 & $.71 *$ & -.16 & .11 & $.62 *$ & - & & & \\
\hline $\mathrm{DO}$ & -.01 & -.12 & -.09 & -.14 & .04 & -.18 & - & & \\
\hline Nitrate & $-.61 *$ & $-.64 *$ & .37 & -.11 & -.45 & -.26 & -.16 & - & \\
\hline Cal & -.38 & $-.54 *$ & .32 & -.19 & $-.48 *$ & -.30 & -.23 & $.80 * *$ & - \\
\hline Magn. & .39 & -.21 & -.49 & -.14 & -.30 & $-.48 *$ & .05 & .10 & .46 \\
\hline Potas. & .32 & -.35 & .14 & -.31 & -.26 & -.64 & .18 & .07 & .12 \\
\hline Amm & -.42 & .23 & -.04 & .10 & .35 & $.72 *$ & -.23 & .37 & .25 \\
\hline Sodium & $-.49 *$ & $-.60 *$ & .4 & -.04 & -.16 & -.08 & .08 & .45 & .27 \\
\hline $\mathrm{P}^{\mathrm{H}}$ & .08 & .11 & -.17 & -.25 & -.03 & .24 & -.23 & .10 & .29 \\
\hline Temp & -.07 & .29 & -.36 & .02 & .06 & .31 & -.24 & -.22 & -.22 \\
\hline Cond. & -.46 & -.49 & .36 & -.05 & -.31 & -.14 & -.18 & $.60 *$ & $.54 *$ \\
\hline Depth & -.11 & -.21 & -.07 & .29 & -.01 & .03 & .31 & -.14 & -.14 \\
\hline Width & -.07 & -.28 & -.16 & .28 & -.35 & -.37 & .10 & .15 & .15 \\
\hline BOD & -.29 & -.22 & .26 & -.04 & $-.54 *$ & -.09 & -.05 & .45 & .45 \\
\hline Vel. & .20 & -.28 & .23 & .12 & -.38 & -.35 & .19 & .29 & .27 \\
\hline Disch. & -02 & -.24 & .10 & .35 & -.34 & -.24 & .13 & .08 & -.03 \\
\hline Transp & .07 & .10 & .12 & -.27 & .04 & -.06 & $-.48 *$ & .08 & -.14 \\
\hline
\end{tabular}

\begin{tabular}{|l|l|l|l|l|l|l|l|l|l|l|l|l|l|}
\hline & $\begin{array}{l}\text { calciu } \\
\mathrm{m}\end{array}$ & $\begin{array}{l}\text { magnesi } \\
\text { um }\end{array}$ & $\begin{array}{l}\text { Potassi } \\
\text { um }\end{array}$ & $\begin{array}{l}\text { Ammoni } \\
\text { um }\end{array}$ & $\begin{array}{l}\text { sodiu } \\
\text { m }\end{array}$ & $\begin{array}{l}\mathrm{pH}--- \\
---\end{array}$ & $\begin{array}{l}\text { Temperat } \\
\text { ure }\end{array}$ & $\begin{array}{l}\text { Conducti } \\
\text { vity }\end{array}$ & $\begin{array}{l}\text { Dep } \\
\text { th }\end{array}$ & $\begin{array}{l}\text { Wid } \\
\text { th }\end{array}$ & $\begin{array}{l}\text { BO } \\
\text { D.. }\end{array}$ & $\begin{array}{l}\text { Veloci } \\
\text { ty }\end{array}$ & $\begin{array}{l}\text { Dischar } \\
\text { ge }\end{array}$ \\
\hline Cal & - & & & & & & & & & & & & \\
\hline Magn & .46 & - & & & & & & & & & & & \\
\hline Potas. & 12 & .43 & - & & & & & & & & & & \\
\hline Amm & .25 & -.26 & $-.49^{*}$ & - & & & & & & & & & \\
\hline
\end{tabular}


Dr Charles Udosen et al.

\begin{tabular}{|l|l|l|l|l|l|l|l|l|l|l|l|l|l|}
\hline $\begin{array}{l}\text { Sodiu } \\
\mathrm{m}\end{array}$ & .27 & -.35 & -.12 & .15 & - & & & & & & & \\
\hline $\mathrm{P}^{\mathrm{H}}$ & .29 & .23 & -.14 & .06 & .15 & - & & & & & & & \\
\hline Temp & -.22 & -.36 & -.44 & .08 & -.14 & .16 & - & & & & & & \\
\hline Cond. & $.54 *$ & -.28 & -.18 & .17 & .43 & .10 & .14 & - & & & & & \\
\hline Depth & -.14 & -.26 & -.38 & -.14 & $.50 *$ & .21 & -.02 & .20 & - & & & & \\
\hline $\begin{array}{l}\text { Widt } \\
\text { h }\end{array}$ & .15 & .24 & -.07 & -.37 & -.03 & -.11 & .07 & .33 & .33 & - & & & \\
\hline BOD & .45 & .19 & -.03 & .06 & .28 & -.40 & -.08 & $.48^{*}$ & .34 & $.63^{*}$ & - & & \\
\hline Vel. & .27 & .39 & .23 & -.27 & .31 & .10 & .01 & $.81^{*} *$ & $.52^{*}$ & $.54^{*}$ & $.64^{*}$ & - & \\
\hline $\begin{array}{l}\text { Disch } \\
.\end{array}$ & -.03 & .03 & -.14 & -.32 & .28 & .11 & -.09 & .01 & $.81^{*}$ & $.52^{*}$ & $.54^{*}$ & $-.52^{*}$ & - \\
\hline $\begin{array}{l}\text { Trans } \\
\mathrm{p}\end{array}$ & -.14 & -.09 & .16 & -.05 & -.31 & -.25 & -.15 & -.04 &.- .13 &.- .15 & -.10 & -.02 & .02 \\
\hline
\end{tabular}

\section{CONClusion}

The study shows that morphology of the stream channels in the lower Enyong Creek are influenced by a combination of both local lithologic controls and moderate hydraulic forces. Detailed morphological assessment also enhances the understanding of channel processes in relation to stream water quality, its natural capability to adjust and depicts the inherent character of the river and possible response to human impact. It provides the basis to develop ecosystem based management for the river.

\section{REFERENCES}

Abowei, J. F. N. (2010). Salinity, Dissolved Oxygen, pH and Surface Water Temperature conditions in Nkoro River, Niger Delta, Nigeria. Advanced Journal of Food Science and Technology, 2 (1), $36-40$.

Abowei, J. F. N., \& Goerge, A. D. I. (2009). Some physical and chemical characteristics in Okpoka Creek; Niger Delta, Nigeria. Research Journal of Environmental and Earth Sciences, 1 (2), $45-$ 53.

Ajao, E. A., \& Fagade, S. O. (2002). The ecology of Neritina glabrata in Lagos Lagoon, Nigeria. Arch. Hyrobiol., 119(3), 339-350.

Akpan, E. R. (1991). Seasonal variation in phytoplankton biomass and pigments in relation to water quality in the Cross River system. Ph. D Thesis, University of Calabar, 179pp.

Andem, A. B., Udofia, U., Okorafor, K. A., Okete, J. A and Ugwumba, A.A.A (2012). A Study on Some Physical and Chemical Characteristics of Ona River, Apata, Ibadan South-west, Oyo State, Nigeria, European Journal of Zoological Research, 1 (2):37-46.

APHA, AWWA, WPCF (2005) Standard Methods for the Examination of Water and wastewater. 20th edition. Washington D.C., American Public Health Association, American Water Works Association, Water Pollution ControlFederation.

Bartram J., Balance R., 1996 Water quality monitoring: a practical guide to the dsign and implementation of freshwater quality studies and monitoring programmes $\mathrm{E}$ and $\mathrm{FN}$ spon. An imprint of Chaoman and Hall, New York.

Chukwu, O., Mustapha, H. I. and Adbdul, G. (2008). The Effect of Minna Abattoir Waste Water on Surface Water Quality. Journal of Environmental Resources. 3:493-497.

Chen, J. C. and Lin, C. Y. (1995). Responses of Oxygen Consumption, Ammonia-N Excretion and Urea-N Excretion of Panaeus chinensis Exposed Ambient Ammonia at Different Salinity and $\mathrm{pH}$ Levels. Journal of Aquaculture. 136: 243-255.

Dan, S. F., Umoh,U.U and Osabor, V.N (2014) Seasonal variation of enrichment and contamination of heavy metals in the surface water of Qua Iboe River Estuary andadjoiningcreeks, South-South Nigeria. Journal of Oceanography and Marine Science Vol. 5(6), pp. 45-54.

Davies, O. A., Ugwumba, A. A., \& Abolude, D. S. (2008). Physico-chemistry quality of Trans-Amadi (Woji) Creek, Port Harcourt, Niger Delta, Nigeria.

Dublin-Green, C. O. (1990). Season variations in some physico-chemical parameters of the Bonny Estuary, Niger Delta. NIOMR Technical Paper, 59:21-25. 
Ekeh, I. B., \& Sikoki, F. D. (2003). The State and Seasonal variability of some pysico-chemical parameters in the New Calabar River, Nigeria. Supp ad Acta Hydrobiol. 5, 45-60.

Ekpo Imaobong E, Chude Louis A, Onuoha Grace C, and Udoh James .P (2012) Studies on the physic-chemical characteristicsand nutrients of a tropical river in southeast Nigeria. Aquaculture, Aquarium, conservation \& Legislation International Journal of the Bioflux Society, volume 5, issue 3.

Ekwu A. O., \& Sikoki, F. D. (2006). Phytoplankton diversity in the Cross River Estuary, Nigeria. Journal of Applied Science and Environmental Management, 10(1): 89-95.

Essien-Ibok, M. A., Akpan, A. W., Udo M. T., Chude, L. A., Umoh, I. A., \& Asuquo, I. E. (2010). Seasonality in the physico-chemical characteristics of Mbo River, Akwa Ibom State, Nigeria. Nign. J. Agric. Fd. Env. 6, 60-72.

Ezekiel E.N, Hart A.I and Abowei J. F.N (2011) The physical and Chemical Condition of Sombreiro River, Niger Delta, Nigeria. Research journalof Environmental and Earth Sciences, Vol.3 (4): 327-340.

Fakayode, S.O.(2005) Impact Assessment of industrial Effluent on Water Quality of the Receiving Alaro River Ibadan, Nigeria. AJEAM-RAGEE,10,1-13.

FEPA (1991). Interim Guidelines and Standards Industrial effluents gaseous emission and Hazards waste management in Nigeria. Federal Environmental protection Agency publication, Lagos, Nigeria, 210p.

Hart, A. I., \& Zabbey, N. (2005). Physico-chemical and benthic fauna of Woji Creek in the Lower Niger Delta, Nigeria. Environ. Ecol., 23(2), 361-368.

Jonnalagadda, S.B. \& Mbere G.2001; water quality of Odzi River in Eastern highland of Zimbabwe, JSc. Direct, 35 ;2371-2376

Leopold LB, Maddock JT. 1953. The hydraulic geometry of stream channels and some physiographic implications. United States Geologic Survey Professional Paper 252; 1-57.

Lowenberg, U., \& Keunzel, T. (1992). Investigation on the Hydrology of the lower Cross River, Nigeria. Anim. Res. Dev., 35, 72-75.

Morenikkeji, O.A and Raheem, N. K (2008). Impact of Abattoir Effluents on Surface Water of Alamuyo Stream Ibadan. Journal of Applied Science Environmental Management. 12 (1) 73-77.

Morgan, D. O. and McManhon, B. R. (1982). Acid Tolerance Effects of Sub-lethal Acid Exposure on Lonoregulation and Acid-base Status in Two Crayfish (Procambarus clarki) and (Orconnectes rusticus). Journal of Experimental Biology. 97: 265-275.

Olatunde S.O and Oladele Osibanjo (2012) Determination of selected heavy metals in inland fresh water of lower River Niger drainage in North Central Nigeria. African Journal of Environmental Science and Technology Vol. 6 (10).pp.403-408.

Offodile, M.E (2002) Ground Water Study and Development in Nigeria. Mecon Geology and Engineering Services Limited, Jos, Nigeria.

Turekian, K. K.,(1977) “The fate of metals in Oceans”. Geochemical et Cosmochimica (1977).

Ubong, I. U., \& Gobo, A. E. (2001). Fundamentals of environmental chemistry and meteorology. Tom and Harry publications Ltd., Port Harcourt, 264p.

Udoh James P, Ukpatu John E and Otoh Aniekan J. (2013) Spatial Variation in Physico-Chemical Parameters of Eastern Obolo Estuary, Niger Delta, Nigeria. Journal of Environment and Earth Science, volume 3, No. 12.

Udoessien, E. I. (2003). Basic principles of environmental Science”, Etiliew International Publishers, Uyo, Nigeria, 339p.

UNESCO/WHO (1978). Water quality survey. Reports in hydrology, No. 23. United Nation Educational Scientific and Cultural Organization and World Health Organization, Paris.

United States Environmental Protection Agency (USEPA), 1979 Quality criteria for U.S. Environmental Protection Agency, 440/9-76023. Washington D.C.

Wetzel, R. G. (2001). Limnology: Lake and River ecosystems, 3rd edn. Academic Press, New York, 1006pp.

WHO, World Health Organization (1984). Guideline for drinking water quality, health criteria and other information Vol.2, Geneva Publication, 306p 


\section{AUTHORS' BIOGRAPHY}

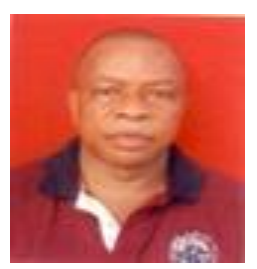

Dr Charles Udosen holds a $\mathrm{PhD}$ degree in Tropical Geomorphology and Hydrology from Nigeria's foremost University, University of Ibadan, Nigeria. He has been teaching at the Department of Geography, University of Uyo, S.E. Nigeria for over two decades. He has served as a consultant to the World Bank; UNDP Consultant on Agro SMEs and Environment. He is a member of many professional bodies and associations such as American Association of Geographers, AAG, International Association of Hydrological Sciences - IAHS, California Society of Geographers, Association of Nigerian Geographers - ANG, International Geospatial Society - IGS. IEEE, Geoscience \& Remote Sensing Society, [IEEE GRSS] African Association of Remote Sensing of the Environment [AARSE], International Association of Sedimentologists [IAS] Nigerian Mining and Geosciences Society (NMGS), International Society for Photogrammetry and Remote Sensing [ISPRS], British Hydrological Society [BHS], International Association of Geomorphologists (IAG). His research work has taken him to several places outside Nigeria like Vienna (Austria, 2012), Clarion University of Pennsylvania 2013 and 2014, University of Florida, Gainville, USA (2013), AAG, Tampa, Fl, USA, (2014); Portland, Oregon, USA May, 2014; Addis Ababa, Ethiopia November, 2013; Gotenburg, Sweden July, 2013 and AAG, Chicago, Il., USA April,2015.

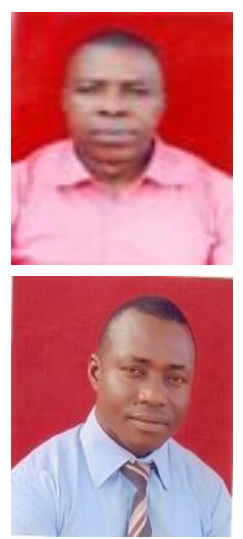

Dr Aniesua A. Essiett holds a PhD degree in Nuclear Physics from Obafemi Awolowo, University, Ile-Ife, S.W. Nigeria. He is currently with the Department of Physics, University of Uyo, S.E. Nigeria and has been teaching numerous courses in Physics. He heads the Post Graduate studies programme in the department.

Mr Abasi-Ifreke Etok is a Chief lecturer in the department of Geography Akwa Ibom State College of Arts and Science, Nung Ukim, Ikono. He holds a Master degree in Urban and Regional Planning from the University of Uyo, 2006. His area of specialization is geomorphology and Regional Planning. He is a member of Association of Nigerian Geographers and Nigerian institute of Town Planners. He has many Journal papers to his credit. 